\title{
Using airborne Ku-band altimeter waveforms to investigate winter accumulation and glacier facies on Austfonna, Svalbard
}

\author{
Robert L. HAWLEY, ${ }^{1}$ Ola BRANDT, ${ }^{2 *}$ Thorben DUNSE, $^{3}$ Jon Ove HAGEN, ${ }^{3}$ Veit HELM, ${ }^{4}$ \\ Jack KOHLER, ${ }^{2}$ Kirsty LANGLEY, ${ }^{3}$ Eirik MALNES, ${ }^{5}$ Kjell-Arild HØGDA ${ }^{5}$ \\ ${ }^{1}$ Department of Earth Sciences, Dartmouth College, Hanover, NH, USA \\ E-mail: Robert.L.Hawley@Dartmouth.Edu \\ ${ }^{2}$ Norwegian Polar Institute, Fram Centre, Tromsø, Norway \\ ${ }^{3}$ Department of Geosciences, University of Oslo, Blindern, Oslo, Norway \\ ${ }^{4}$ Alfred Wegener Institute Helmholtz Center for Polar and Marine Research, Bremerhaven, Germany \\ ${ }^{5}$ Norut IT, Forskningsparken, Tromsø, Norway
}

\begin{abstract}
Winter balance is an important metric for assessing the change on glaciers and ice caps, yet measuring it using ground-based techniques can be challenging. We use the European Space Agency prototype Airborne SAR/Interferometric Radar Altimeter System (ASIRAS) to extract snow depths from the received altimeter waveforms over Austfonna ice cap, Svalbard. Additionally, we attempt to distinguish the long-term firn area from other glacier facies. We validate our results using snow depth and glacier facies characterizations determined from ground-based radar profiles, snow pits and a multilook satellite synthetic aperture radar image. We show that the depth of the winter snowpack can be extracted from the altimeter data over most of the accumulation zone, comprising wet snow zone and a superimposed ice zone. The method struggles at lower elevations where internal reflections within the winter snowpack are strong and the winter snow depth is less than $\sim 1 \mathrm{~m}$. We use the abruptness of the reflection from the last summer surface (LSS) to attempt to distinguish glacier facies. While there is a general correlation between LSS abruptness and glacier facies, we do not find a relationship that warrants a distinct classification based on ASIRAS waveforms alone.
\end{abstract}

\section{INTRODUCTION}

Space- and airborne radar altimeters have proven to be one of the best tools for measuring surface elevation changes of large ice sheets over time (Alley and others, 2007; Rignot and others, 2008, 2011; Zwally and Giovinetto, 2011; Shepherd and others, 2012). Over ice, elevation differences between two epochs yield the volume change, and after correction for density variations of the overlying firn the mass change between the two measurements can be derived.

Radar altimeters determine the range between the radar (on the air- or spacecraft) and the target (the Earth's surface) by transmitting electromagnetic waves and recording the return power after some time delay. These waves may penetrate several meters into snow, firn and ice (Arthern and others, 2001; Hawley and others, 2006; Helm and others, 2007; Lacroix and others, 2007). The degree of penetration and scattering depends on the physical properties of the material, which can vary both spatially and temporally and thus affect the received waveforms (Scott and others, 2006a,b). Since radar altimeters have relatively large footprints, subsurface returns can be combined with the returns from surrounding surface topography. Thus it can be a challenge to pinpoint the surface elevation from the received waveforms (Alley and others, 2007; Brenner and others, 2007). The performance of radar altimeters is generally best in the interiors of the large ice sheets, where the surface is relatively flat and seasonal fluctuations in material properties small. Performance is reduced at the ice-sheet margins, as well as over small

*Present address: Norwegian Coastal Administration - Kystverket, Ålesund, Norway. glaciers and ice caps characterized by steep surface slopes and large seasonal variations in material properties due to surface melting. The largest contribution to current sea-level rise, attributed to land ice melt, is from small ice caps and glaciers (Lemke and others 2007; Meier and others 2007; Cogley, 2009; Church and others, 2011). Thus, there is an urgent need to improve the understanding of radar altimeter returns from ice caps and glaciers, and their seasonal variations, in order to successfully monitor these important changes. Additionally, observations from small ice caps and glaciers can improve our ability to detect changes in the ablation areas of the larger ice sheets.

While subsurface returns may raise challenges for surface retracking with radar altimeters, these waveforms provide a potential source from which subsurface information can be extracted. Lacroix and others (2007) used the European Space Agency's (ESA) dual-frequency Envisat altimeter data to extract subsurface characteristics over the Amery Ice Shelf, Antarctica. Over the Greenland dry snow zone, Hawley and others (2006) showed agreement between subsurface radar altimeter returns and annually resolved firn density fluctuations using ESA's Airborne SAR/Interferometric Radar Altimeter System (ASIRAS). This system was also used by Helm and others (2007) to map the winter accumulation along a flight line in the percolation zone of the Greenland ice sheet.

König and others (2002) showed that different glacier facies in Svalbard can, under certain circumstances, be classified using satellite synthetic aperture radar (SAR) imagery. Hindberg and others (2012) studied the variability in glacier facies over the period 2002-12 using Envisat ASAR. Langley and others (2007, 2008), Brandt and others 


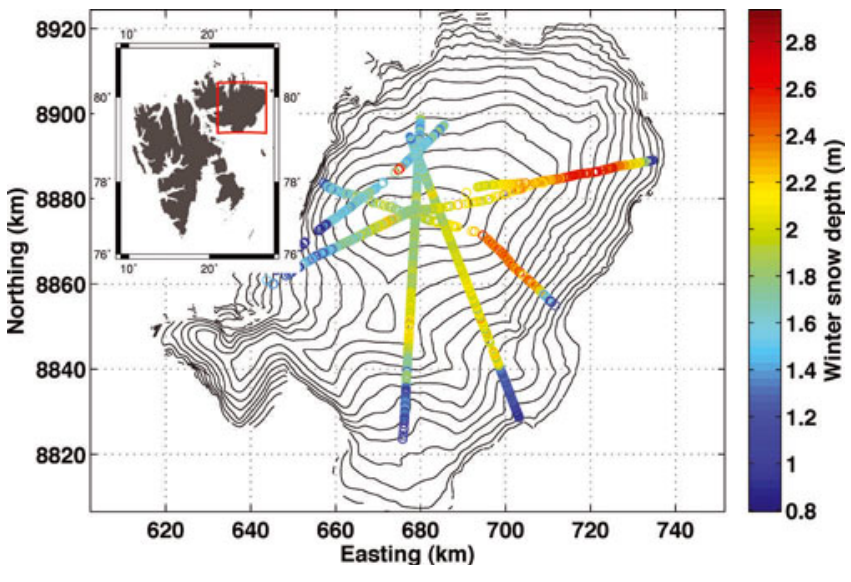

Fig. 1. Winter snow depth as determined by airborne altimeter data (ASIRAS), acquired between 18 and 21 April 2007. Accumulation is generally higher on the east side of the ice cap and and lower to the west. Universal Transverse Mercator (UTM) coordinates in zone 33X. Ice-cap elevation is given in $100 \mathrm{~m}$ contour intervals. Inset: location map of Austfonna, Svalbard.

(2008) and Dunse and others (2009) compared groundpenetrating radar (GPR) and SAR backscatter to determine glacier facies. This correspondence between sounding-radar backscatter and facies gives rise to the potential of using ASIRAS backscatter to determine glacier facies.

In this study we apply methods similar to Helm and others (2007) to derive snow accumulation along several ASIRAS altimeter profiles crossing over Austfonna ice cap, Svalbard. The method involves tracking the last year's summer surface (LSS), buried beneath winter snow accumulation, in the radar waveform data. We outline a robust retracking scheme that accounts for considerable variations in the retrieved waveforms from different glacier facies. Additionally, we attempt to use the characteristics of the subsurface returns to distinguish the long-term firn area from the other facies. Generally, the power of the LSS reflection is lower in the long-term firn area, as is the the abruptness of the LSS reflection, as we expect. Despite these general correlations, a quantitative classification of facies using ASIRAS remains elusive.

\section{FIELD SITE: AUSTFONNA}

Austfonna ice cap $\left(8120 \mathrm{~km}^{2} ; 79.7^{\circ} \mathrm{N}, 24.0^{\circ} \mathrm{E}\right)$ on Svalbard (Fig. 1, inset) has been the focus of several studies starting as early as 1873 and summarized by Taurisano and others (2007). The ice cap reaches a maximum elevation of $800 \mathrm{~m}$ a.s.l., with one dome supplying a number of drainage basins. Several methods have been applied to determine the surface mass balance (Pinglot and others, 2001; Schuler and others, 2007; Taurisano and others, 2007; Dunse and others, 2009), surface elevation changes (Bamber and others, 2004; Moholdt and others, 2010) and dynamics (Bevan and others, 2007; Dowdeswell and others, 2008). Despite a recent surface mass balance close to zero (Moholdt and others, 2010), the ice cap experiences net mass loss attributed to calving and retreat of the marine ice margin (Dowdeswell and others, 2008). On Austfonna, melt and rain events can occur even during winter. In summer, surface temperatures typically remain above or around freezing (T.V. Schuler and others, unpublished information). This causes extensive melting, percolation and refreezing. The firn is therefore heterogeneous and characterized by ice lenses, glands, and layers ranging in thicknesses from millimeters to $>0.5 \mathrm{~m}$. Thus, in most years the facies in the accumulation area of Austfonna will consist of a wet snow zone and a superimposed ice zone as defined by Paterson (1994).

\section{DATA AND METHODS}

\section{Airborne altimeter data}

The airborne radar altimeter data were collected at the end of April 2007 using ESA's ASIRAS system (Hawley and others, 2006; Helm and others, 2007). The instrument was operated in a non-interferometric mode at a nominal altitude of $\sim 700 \mathrm{~m}$ above the surface. The instrument is a frequency-modulated nadir-viewing SAR with a $13.5 \mathrm{GHz}$ center frequency (Ku band) and $1 \mathrm{GHz}$ bandwidth (Lentz and others, 2002).

The raw radar data were post-processed using ESA's ASIRAS L1b processor. The processor uses Doppler frequency shift to coherently focus the beam in the along-track direction, giving an effective footprint of $\sim 5 \mathrm{~m}$ along track by $\sim 50 \mathrm{~m}$ across track. Positioning of the radar traces comes from differential GPS (DGPS) and an inertial navigation system. The distance between each trace recorded by ASIRAS (after post-processing) depends on aircraft speed relative to the ground, but is typically $8-10 \mathrm{~m}$.

We determined the electromagnetic wave velocity in snow down to the LSS using a ground-based stepped frequency Ku-band radar (Brandt and others, 2008) and from density profiles derived in pits (see next subsection).

The electromagnetic wave speed $\nu\left(\mathrm{m} \mathrm{s}^{-1}\right)$ is related to the real part of the dielectric permittivity $\epsilon_{\mathrm{r}}$ (dimensionless) and the speed of light in a vacuum $c\left(\sim 3 \times 10^{8} \mathrm{~m} \mathrm{~s}^{-1}\right)$ by

$$
\nu=\frac{C}{\sqrt{\epsilon_{\mathrm{r}}}} \text {. }
$$

The relative permittivity of snow and firn is related to density $\rho\left(\mathrm{kg} \mathrm{m}^{-3}\right)$ following (Kovacs and others, 1995)

$$
\epsilon_{\mathrm{r}}=\left(1+8.45 \times 10^{-4} \rho\right)^{2} .
$$

During the measurements the winter snow temperature ranged from $-5^{\circ} \mathrm{C}$ to $-23^{\circ} \mathrm{C}$, fulfilling the criteria of a dry snowpack for the empirical conversion using Eqn (2). Below the LSS the propagation velocity is more spatially variable depending on the glacier zone in which the measurement is made. Because the main focus of this study is on the winter snowpack and the shape and power of the LSS reflection, we have not made further velocity corrections below the LSS. The mean density of our 14 snow pits in 2007 was $390 \mathrm{~kg} \mathrm{~m}^{-3}$, with a standard deviation of $21 \mathrm{~kg} \mathrm{~m}^{-3}$. Our resulting wave speed velocity $\nu$ is $\left(2.25 \times 10^{8}\right) \pm$ $\left(0.03 \times 10^{8}\right) \mathrm{m} \mathrm{s}^{-1}$, and is uniform across our survey area.

The range resolution of the altimeter, determined by the bandwidth and wave velocity of the radar (Hamran and others, 1995), is $\sim 0.15$ and $\sim 0.11 \mathrm{~m}$ in air and the winter snowpack respectively. Some of the profiles from the April 2007 campaign suffer from poor data quality, mainly due to rapid and high-amplitude aircraft movements (Helm and others, 2007), and have been discarded.

\section{Ground-based data}

To validate the ASIRAS measurements and interpretation, we use GPR data collected at a frequency of $800 \mathrm{MHz}$ in spring 2007 (Dunse and others, 2009). The GPR profiles were 
located using DGPS measurements and are supplemented by physical snow properties measurements in snow pits (two to four in each profile). The two-way travel time of the radar wave was converted to depth using the method described above for ASIRAS, and validated using manual snow depth soundings. Lateral variations of the average density of the entire winter snowpack were found to be small, and the related uncertainty in depth determination of the LSS is on the order of $\pm 5 \mathrm{~cm}$, which is small compared to the effective resolution of the GPR, estimated by Dunse and others (2009) to be $\sim 0.25 \mathrm{~m}$. Dunse and others (2009) compared SAR backscatter with GPR-derived glacier facies and subclassified the firn area into three zones: a long-term firn area (F1); a firn layer that originates from multiple years of accumulation but lies in a zone of recent ( $\sim 10$ years) variability of the firn line (F2); and a thin firn layer that apparently originates from one accumulation season only (F3). Zones F2 and F3 are either underlain by superimposed ice (SI) or ice typical of the ablation zone. A series of GPR measurements from four consecutive spring seasons enabled delineation of a multi-year sequence of glacier facies distribution.

\section{Satellite SAR data}

The SAR image used in this study is a composite multi-look two-dimensional backscatter image from the Advanced Synthetic Aperture Radar (ASAR) on board ESA's Envisat.

In total, 75 Envisat ASAR wide swath medium-resolution $(150 \mathrm{~m})$ images covering Austfonna for the winter season 2006/07 were used. The images were in both $\mathrm{HH}$ - and VVpolarization and covered all incidence angles from $17^{\circ}$ to $42^{\circ}$ (400 km swath). The difference between $\mathrm{HH}$ and VV was investigated, and found to be insignificant compared to the temporal variability.

These scenes were calibrated and georeferenced to result in a final multi-look image with $50 \mathrm{~m}$ pixel spacing. Each image was corrected for incidence angle variability applying the Muhleman distribution (Muhleman, 1964) and averaged to obtain a SAR image with improved radiometric properties on which the long-term firn area is easily identified by its higher backscatter. A variety of other incidence angle corrections were tested, including correction to the mean incidence angle of $30^{\circ}$ using linear fitting to the data itself (Sabel and others, 2012) and correction using the method by Ulander (1996). We found only small differences in the final averaged result, and the Muhleman distribution was preferred due to its simplicity.

Here we compare the ASIRAS-derived LSS abruptness (described below) and total power with SAR images from winter 2006/07 (the same year in which our ground- and air-based data were collected). This is in contrast to Dunse and others (2009) who used a longer time series of SAR images and GPR, relating GPR-derived glacier facies with SAR backscatter.

\section{Methods}

\section{Surface and LSS retracking}

We tracked the snow surface using a simple but robust threshold retracker. Since the maximum power of each trace varies depending on permittivity contrasts, surface orientation relative to the radar beam, and other factors, we use a relative threshold for each individual radar profile. We set our threshold to $20 \%$ of the mean peak amplitude over all traces in the profile. If the retracker fails, this manifests itself as a discontinuity in the surface. In case of discontinuities in tracking position (typically only a few percent of the points in each profile), a 10\% threshold retracking point was used. Traces causing anomalous surface elevations for both thresholds and traces with anomalously low maximum power $(<2 \times$ threshold) were discarded. The roll angle of the aircraft can have a significant effect on the return waveform shape and can lead to retracking errors, so we excluded any data in which the aircraft roll exceeded $\pm 1.5^{\circ}$. After surface retracking, we anchor the depth scale for the radar profile to zero at the retracked surface. To save computational time and memory, the data have been decimated by a factor of two; only every other trace is used and illustrated.

Retracking of the LSS is complicated by significant spatial variations in LSS reflection power over the study area. In contrast to Helm and others (2007), a single threshold algorithm failed to track the LSS reflection in a consistent way. Instead we used a local peak-finding algorithm in which only local peaks separated by a minimum depth distance are picked (set to seven range bins or $\sim 0.75 \mathrm{~m}$ ). By setting this distance large enough, the algorithm ignores smaller peaks (likely due to ice lenses and layers within the snowpack) that may occur close to larger local peaks. The peak position (in depth) is then compared to the surrounding traces both in number of peaks detected and position of the peaks to avoid the re-tracker 'jumping' between the LSS reflection and another peak adjacent in depth.

\section{Winter snow depth comparison}

We calculated the difference between winter snow depth as mapped with GPR (Dunse and others, 2009) and with the ASIRAS data. For each ASIRAS-derived snow depth position, we linearly interpolated and resampled the GPR-based snow depths to the same position along the track. The spatial offset between profiles is generally less than a few tens of meters, with some exceptions.

\section{Power and abruptness index}

To determine glacier facies, we calculated the maximum peak power and an abruptness index of the LSS reflection for each waveform. The peak power of the LSS reflection $P_{\text {peak }}(x)$ is computed by taking the average power of the three range bins surrounding the retracked LSS point. Since the received power from the LSS depends on the reflectivity (permittivity contrast) of the interface as well as the amount of power scattered above the interface and losses due to absorption, we normalized the LSS peak power to the total received power. To determine the abruptness of the LSS peak signal, following Oswald and Gogineni (2008) we calculated an abruptness index of the LSS reflection as a proxy for the shape of the waveform. The abruptness index $I_{\mathrm{abr}}(x)$ at position $x$ along the track is taken as

$$
I_{\mathrm{abr}}(x)=\frac{P_{\text {peak }}(x)}{\sum_{z-2}^{z+10} P(x, z)}
$$

where $\sum_{z-2}^{z+10} P(x, z)$ is the aggregate reflection power over the interval from two bins above the location of maximum power to ten bins below. Thus, a well-defined peak, appearing as a spike, will have a higher abruptness index than a peak with the same maximum power but surrounded by bins with similarly high power. 


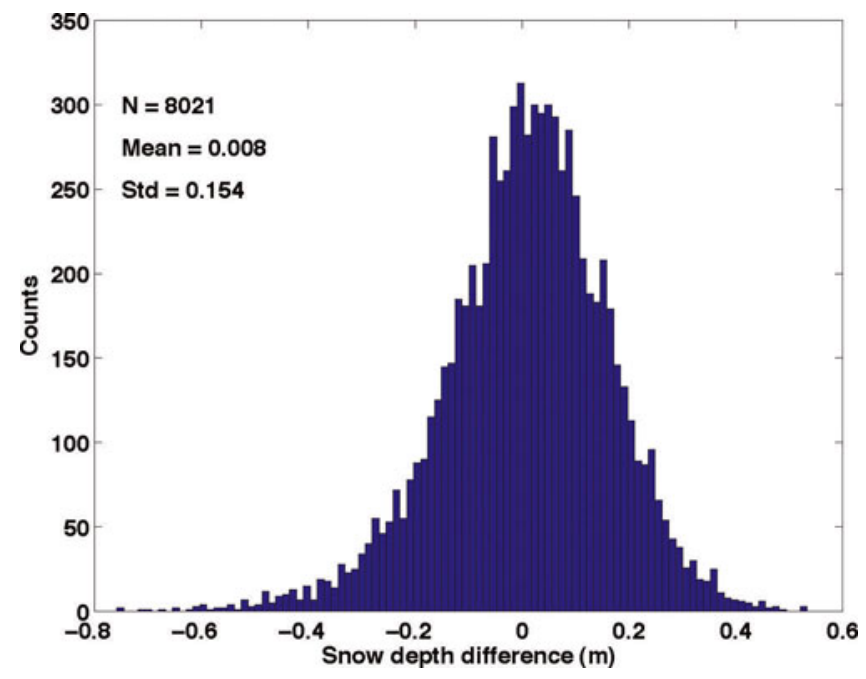

Fig. 2. Histogram of the difference between winter snow depth retrieved using the airborne ASIRAS altimeter instrument and the corresponding ground-based winter snow depth measurements from Dunse and others (2009). The distribution is normal, with a mean of $0.008 \mathrm{~m}$ and standard deviation of $0.154 \mathrm{~m}$.

\section{RESULTS}

\section{Winter snow depth}

The winter snow depth as retrieved by ASIRAS (Fig. 1) shows an asymmetric accumulation pattern across Austfonna, with increasing snow accumulation from northwest to southeast. Comparing the airborne retracked winter snow depth with the ground-based snow depth data from Dunse and others (2009) we find a mean offset of $0.008 \mathrm{~m}$ (ground-based minus airborne) with a standard deviation of $0.154 \mathrm{~m}$ over the total profile length (Fig. 2). Spatially, the two methods correspond closely over most of the ice cap (Fig. 3), except for three sites at lower elevations. The lower-accumulation and -ablation sites pose some challenges to the retracking algorithm. Here reflections from within the winter snowpack are strong relative to the LSS reflection, and reflectors become more closely spaced as the snow depth decreases, confounding the LSS retracking algorithm.

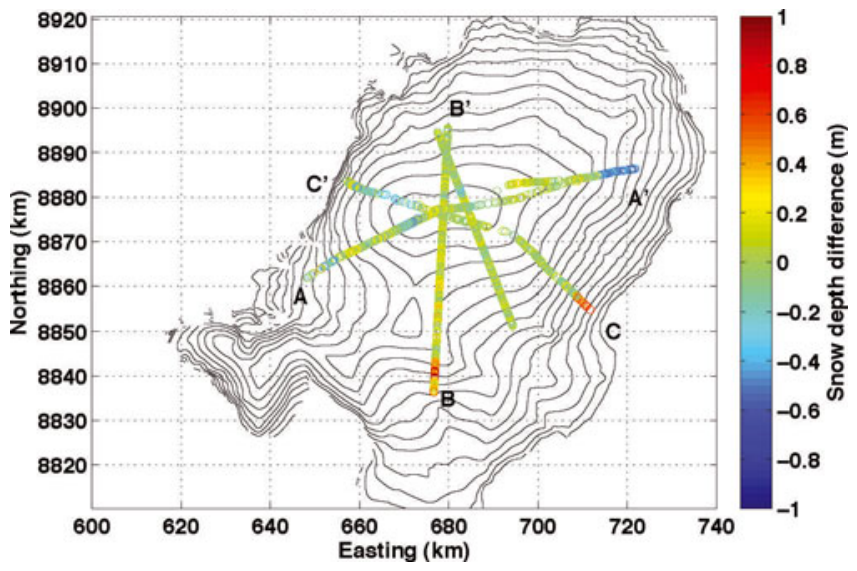

Fig. 3. Winter snow depth difference $(m)$ between the ground-based (Dunse and others, 2009) and airborne altimeter data (ASIRAS). Three representative profiles are marked $A-A^{\prime}, B-B^{\prime}$ and $C-C^{\prime}$, and are illustrated in Figure 5. Ice-cap elevation is given in $100 \mathrm{~m}$ contour intervals.

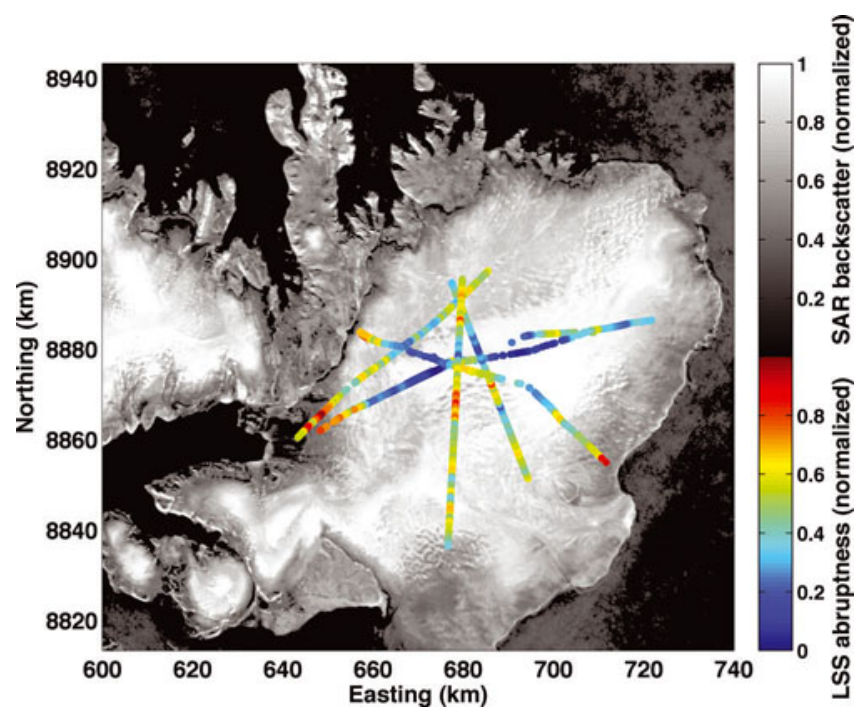

Fig. 4. Airborne ASIRAS-tracked LSS abruptness (normalized color) overlaid on multi-looked satellite SAR image (normalized grayscale). The long-term firn area corresponds to the high backscatter (white) in the SAR image. This area is characterized in the ASIRAS data by a lower LSS abruptness.

\section{Glacier facies}

We find the abruptness of the LSS reflection to be lower in the long-term firn area than in other glacier facies (Fig. 4). The highest abruptness (most well-defined peak) is found where the winter snowpack overlies ice and within the area over which the firn line has been fluctuating over recent years (Dunse and others, 2009). In contrast, the total reflection power does not seem to show any clear relation to glacier facies or snow depth. Instead it is highly influenced by the power of the LSS reflection, internal backscatter within the winter snowpack, and the power of the surface/near-surface return.

\section{DISCUSSION}

\section{Snow depth}

The ASIRAS and snow thickness data agree to within $0.008 \mathrm{~m}$, despite the fact that the measurements were done with different spatial offsets, on different days and with significantly different footprint size.

Notably, there are three areas illustrated in Figure 3 where the airborne radar processing fails to accurately retrieve winter snow depth. These three profiles $\left(A-A^{\prime}, B-B^{\prime}\right.$ and $C-C^{\prime}$ in Fig. 3) are shown in their entirety in Figure 5. The regions in question are $60-70 \mathrm{~km}$ along profile $A-A^{\prime}, 15-$ $20 \mathrm{~km}$ along profile $\mathrm{B}-\mathrm{B}^{\prime}$ and $0-5 \mathrm{~km}$ along profile $\mathrm{C}-\mathrm{C}^{\prime}$. In the first instance, the airborne retracker appears to successfully track the same layer, but the ground-based radar clearly recorded a different surface as the LSS. In the next two profiles, the snow is getting relatively thin. Since we identify peaks that are at least $0.75 \mathrm{~m}$ apart to track the LSS, as the snowpack thins we encounter the limitations of the method.

At a few locations within the long-term firn area, over distances shorter than $50 \mathrm{~m}$, the LSS reflection is weak and the retracker tracks deeper reflectors. This is manifested in the LSS depth record as discontinuities in depth. In most cases, these sudden changes in depth can easily be filtered, but this would be a potential problem if larger areas with these types of waveforms were encountered. 


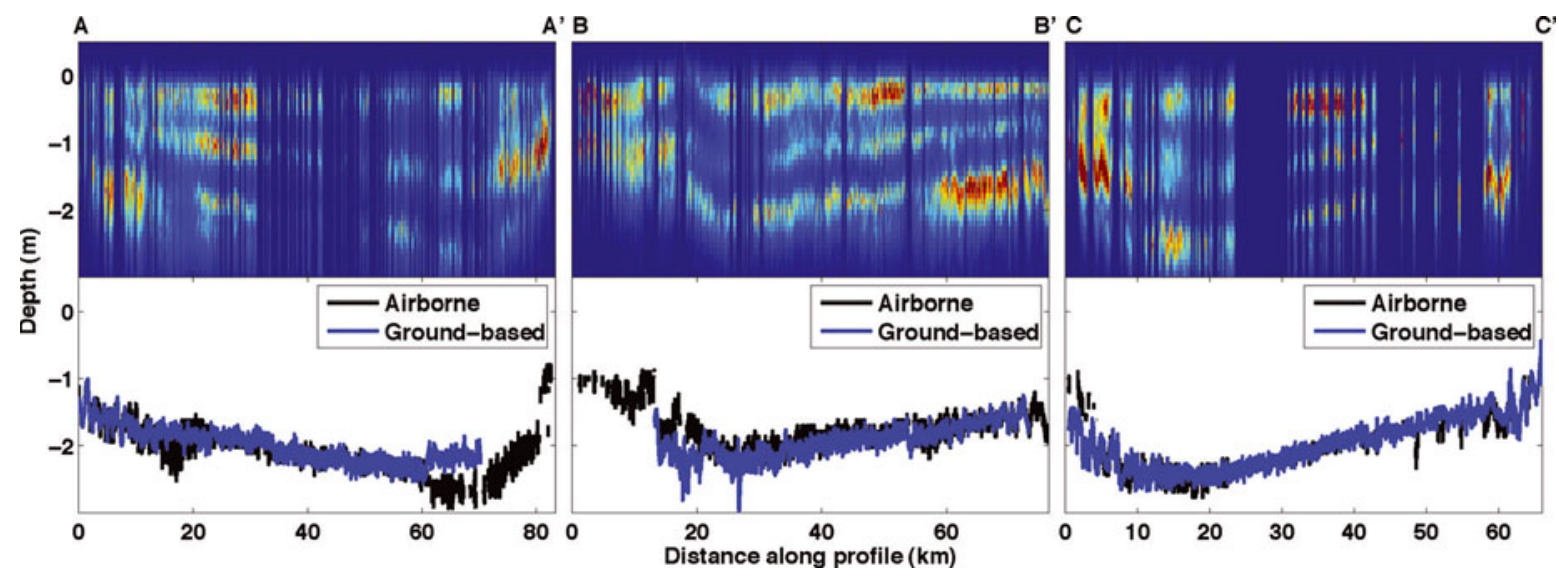

Fig. 5. Upper panels: The full length of the airborne altimeter profiles $A-A^{\prime}, B-B^{\prime}$ and $C-C^{\prime}$ in Figure 3 . Radar data have been masked (and eliminated from our analysis) where aircraft roll exceeded $\pm 1.5^{\circ}$. These areas are evident as 'dropouts' in the radargram. Lower panels: Retracked LSS surface from the airborne radar in black, and corresponding LSS depth inferred from ground-based measurements (Dunse and others, 2009) in blue.

Evident in Figure 5 is an internal reflecting layer within the winter snowpack, distinct from the surface and LSS return. This reflector may represent one or more events (e.g. storms) which caused a discontinuity in snow density, giving rise to a contrast in permittivity. In areas with snow depths shallower than $\sim 1 \mathrm{~m}$, strong internal reflection horizons within the winter snow are closely spaced with the reflection from the LSS, hampering unambiguous retracking of the LSS. We have not found a way to overcome this problem since we have limited ground-based data close to the margins to support testing of other methods (the presence of crevasses restricts safe access at several locations). Further work is therefore needed to evaluate the performance of ASIRAS at low-accumulation sites. These results therefore show that the methods outlined here cannot be applied to an area without direct ground-based verification. This emphasizes the need for independent ground-truth measurements in these types of regions.

The airborne data were collected over 3 days, while the ground-based data were recorded over a 2 week period during which redeposition of snow by wind drift and new snowfall was observed. This effect appears to be minimal, as we do not find a consistent pattern in snow depth differences along profiles recovered on different days. Over the eastern flank of Austfonna the field team observed significant and varied surface roughness, with sastrugi heights up to 40 $50 \mathrm{~cm}$. In the airborne data we do not see any clear effect from this.

\section{Facies}

Langley and others $(2007,2008)$ and Dunse and others (2009) successfully determined glacier facies from groundbased radar surveys. Therefore it seemed worth seeing whether it would also be possible to determine facies from airborne radar. Because electromagnetic energy is reflected from surfaces with strong dielectric contrasts, and because density differences provide the strongest dielectric contrasts in the near-surface glacier regime, the stronger density contrast of snow on glacial ice should give a stronger response than the weaker contrast of snow over long-term firn. For this reason we investigated both the power of the LSS reflecting horizon and its abruptness. The high power of the LSS reflection between 60 and $80 \mathrm{~km}$ along the line B-B' in Figure 5 is an example of what we might expect to see in the SI or ablation facies, and it is indeed the transition between this and the long-term firn area that we see in this region (Fig. 4). Though the power shows the kind of behavior we would expect in this instance, it is not consistent across the ice cap. For this reason we turn to a measure of the abruptness of the LSS peak.

In the SI and ablation facies of the ice cap, the LSS peak should be very abrupt, as most of the energy is reflected at the interface between winter snow and glacial ice. Further, dielectric contrasts below the snow ice contact do not yield reflections of comparable power. Thus it follows that abruptness of the LSS peak may serve as an indicator of facies. In determining facies from the abruptness of the LSS peak, we note in Figure 4 that there is a general correspondence between lower abruptness of the LSS peak and higher SAR backscatter, implying that the lower LSS abruptness can be used as an indicator for the firn area. However, in seeking a quantitative relationship between LSS abruptness and SAR backscatter, we do not find a compelling enough correlation to warrant classification of facies solely from ASIRAS radar waveforms.

\section{Extension to spaceborne radar altimeters}

The success with which ASIRAS penetrates winter snow and firn in the percolation zone (this work; Helm and others 2007) and in the dry-snow zone (Hawley and others 2006) makes it attractive to extend similar analyses to spaceborne radar altimeters, such as that flown aboard ESA's CryoSat-2. Such an application faces distinct challenges. The first of these challenges is that of range resolution: the resolution of CryoSat-2's radar is $\sim 47 \mathrm{~cm}$ in air (Wingham and others 2005), and, though the range resolution in snow will be slightly finer, the entire thickess of the winter snow in our survey area would be represented by five to ten range bins, making many of the techniques we use for identifying the LSS impossible. In addition, the footprint size of a spaceborne radar altimeter is significantly larger, and contributions to the echo from off-nadir returns (surface clutter) are likely to be combined with subsurface returns, obscuring the LSS.

\section{CONCLUSIONS}

We have used airborne ASIRAS altimeter waveforms to map winter snow accumulation in the accumulation and upper 
ablation zone of Austfonna. The accumulation area is typically exposed to extensive summertime melt and is thus composed of a wet snow zone and a SI zone. We used a local peak-finding algorithm to retrack the LSS. This contrasts with the method of Helm and others (2007), which used a threshold retracker to follow the LSS horizon in a profile from Greenland's percolation zone. In our case, a similar threshold retracking failed due to large spatial variations of the received power returns from the LSS over Austfonna.

The depth of LSS, as tracked in the ASIRAS data, agrees within $\sim 0.008 \mathrm{~m}$ with ground-based measurements of snow thickness, the latter based on manual snow depth probing and GPR (Dunse and others, 2009). Snow depth retrieved by ASIRAS differs slightly from snow depth retrieved by GPR at lower-elevation and lower-accumulation sites. This emphasizes the need for independent ground-truth measurements to verify the airborne data in these regions. It also demonstrates the need for further investigations at low winter snow accumulation sites close to the equilibrium line and within the ablation zone. In spite of this need, ASIRAS can be a useful tool for measuring winter balance on glaciers and small ice caps such as Austfonna.

The LSS power (after normalization to the total received power) and its abruptness are both lower over the long-term firn area compared to the other encountered glacier facies. These differences can potentially be used to delineate the long-term firn area from the superimposed ice and ablation zone. Though we note a general correspondence between lower LSS abruptness and higher SAR backscatter, consistent with our predictions, the relationship between the two is clearly more complex and we do not find a distinct classification of glacier facies based on ASIRAS radar waveforms at Austfonna.

\section{ACKNOWLEDGEMENTS}

This work was supported by the European Space Agency (ESA) and the Norwegian Space Center as part of the CryoSat program and by the Norwegian Research Council through the International Polar Year (IPY) project GLACIODYN. This work was also funded in part by the German Ministry of Economics and Technology (grant 50EE1008). Envisat ASAR data were provided by ESA under IPY AO contract No. 4122. We thank the aircrews who flew the ASIRAS data flights for their work. We are especially grateful to Trond Eiken for carrying out the ground-based GPR and GPS work. The manuscript benefited greatly from the comments of Ginny Catania and Jo Jacka, Scientific Editors, and two anonymous reviewers.

\section{REFERENCES}

Alley RB, Spencer MK and Anandakrishnan S (2007) Ice-sheet mass balance: assessment, attribution and prognosis. Ann. Glaciol., 46, 1-7 (doi: 10.3189/172756407782871738)

Arthern RJ, Wingham DJ and Ridout AL (2001) Controls on ERS altimeter measurements over ice sheets: footprint-scale topography, backscatter fluctuations, and the dependence of microwave penetration depth upon satellite orientation. J. Geophys. Res., 106(D24), 33 471-33 484 (doi: 10.1029/2001JD000498)

Bamber J, Krabill W, Raper V and Dowdeswell J (2004) Anomalous recent growth of part of a large Arctic ice cap: Austfonna, Svalbard. Geophys. Res. Lett., 31(12), L12402 (doi: 10.1029/ 2004GL019667)
Bevan S, Luckman A, Murray T, Sykes H and Kohler J (2007) Positive mass balance during the late 20th century on Austfonna, Svalbard, revealed using satellite radar interferometry. Ann. Glaciol., 46, 117-122 (doi: 10.3189/172756407782871477)

Brandt $\mathrm{O}$ and 7 others (2008) Comparison of airborne radar altimeter and ground-based Ku-band radar measurements on the ice cap Austfonna, Svalbard. In 28th International Geoscience and Remote Sensing Symposium (IGARSS 2008), 6-11 July 2008, Boston, MA, USA. Proceedings, Vol. 4. Institute of Electrical and Electronics Engineers, Piscataway, NJ, 177-180

Brenner AC, DiMarzio JP and Zwally HJ (2007) Precision and accuracy of satellite radar and laser altimeter data over the continental ice sheets. IEEE Trans. Geosci. Remote Sens., 45(2), 321-331 (doi: 10.1109/TGRS.2006.887172)

Church JA and 9 others (2011) Revisiting the Earth's sea-level and energy budgets from 1961 to 2008. Geophys. Res. Lett., 38(18), L18601 (doi: 10.1029/2011GL048794)

Cogley JG (2009) Geodetic and direct mass-balance measurements: comparison and joint analysis. Ann. Glaciol., 50(50), 96-100 (doi: 10.3189/172756409787769744)

Dowdeswell JA, Benham TJ, Strozzi T and Hagen JO (2008) Iceberg calving flux and mass balance of the Austfonna ice cap on Nordaustlandet, Svalbard. J. Geophys. Res., 113(F3), F03022 (doi: 10.1029/2007JF000905)

Dunse T, Schuler TV, Hagen JO, Eiken T, Brandt O and Høgda KA (2009) Recent fluctuations in the extent of the firn area of Austfonna, Svalbard, inferred from GPR. Ann. Glaciol., 50(50), 155-162 (doi: 10.3189/172756409787769780)

Hawley RL, Morris EM, Cullen R, Nixdorf U, Shepherd AP and Wingham DJ (2006) ASIRAS airborne radar resolves internal annual layers in the dry-snow zone of Greenland. Geophys. Res. Lett., 33(4), L04502 (doi: 10.1029/2005GL025147)

Helm V and 6 others (2007) Winter accumulation in the percolation zone of Greenland measured by airborne radar altimeter. Geophys. Res. Lett., 34(6), L06501 (doi: 10.1029/ 2006GL029185)

Hindberg H, Malnes E and Hogda KA (2012) A monitoring system for glaciers on Svalbard based on Envisat ASAR wide swath data. In International Geoscience and Remote Sensing Symposium (IGARSS 2012), 22-27 July 2012, Munich, Germany. Proceedings. Institute of Electrical and Electronics Engineers, Piscataway, NJ, 1856-1859

König M, Wadham J, Winther JG, Kohler J and Nuttall A-M (2002) Detection of superimposed ice on the glaciers Kongsvegen and midre Lovénbreen, Svalbard, using SAR satellite imagery. Ann. Glaciol., 34, 335-342 (doi: 10.3189/172756402781817617)

Kovacs A, Gow AJ and Morey RM (1995) The in-situ dielectric constant of polar firn revisited. Cold Reg. Sci. Technol., 23(3), 245-256 (doi: 10.1016/0165-232X(94)00016-Q)

Lacroix P, Legrésy B, Coleman R, Dechambre M and Rémy F (2007) Dual-frequency altimeter signal from Envisat on the Amery iceshelf. Remote Sens. Environ., 109(3), 285-294 (doi: 10.1016/ j.rse.2007.01.007)

Langley K and 6 others (2007) Use of C-band ground penetrating radar to determine backscatter sources within glaciers. IEEE Trans. Geosci. Remote Sens., 45(5), 1236-1246 (doi: 10.1109/ TGRS.2007.892600)

Langley K and 6 others (2008) From glacier facies to SAR backscatter zones via GPR. IEEE Trans. Geosci. Remote Sens., 46(9), 2506-2516 (doi: 10.1109/TGRS.2008.918648)

Lemke P and 10 others (2007) Observations: changes in snow, ice and frozen ground. In Solomon S and 7 others eds. Climate change 2007: the physical science basis. Contribution of Working Group I to the Fourth Assessment Report of the Intergovernmental Panel on Climate Change. Cambridge University Press, Cambridge, 339-383

Lentz $\mathrm{H}$, Braun $\mathrm{H}-\mathrm{M}$, Younis $\mathrm{M}$, Fischer $\mathrm{C}$, Wiesbeck $\mathrm{W}$ and Mavrocordatos C (2002) Concept and realization of an Airborne SAR/Interferometric Radar Altimeter System (ASIRAS). In Inter- 
national Geoscience and Remote Sensing Symposium (IGARSS 2002), 24-28 June 2002, Toronto, Canada. Proceedings, Vol. 6. Institute of Electrical and Electronics Engineers, Piscataway, NJ, 3099-3101

Meier MF and 7 others (2007) Glaciers dominate eustatic sea-level rise in the 21st century. Science, 317(5841), 1064-1067 (doi: 10.1126/science.1143906)

Moholdt G, Hagen JO, Eiken T and Schuler TV (2010) Geometric changes and mass balance of the Austfonna ice cap, Svalbard. Cryosphere, 4(1), 21-34 (doi: 10.5194/tcd-3-857-2009)

Muhleman DO (1964) Radar scattering from Venus and the Moon. Astron. J., 69(1), 34-41

Oswald GKA and Gogineni SP (2008) Recovery of subglacial water extent from Greenland radar survey data. J. Glaciol., 54(184), 94-106 (doi: 10.3189/002214308784409107)

Paterson WSB (1994) The physics of glaciers, 3rd edn. Elsevier, Oxford.

Pinglot JF, Hagen JO, Melvold K, Eiken T and Vincent C (2001) A mean net accumulation pattern derived from radioactive layers and radar soundings on Austfonna, Nordaustlandet, Svalbard. J. Glaciol., 47(159), 555-566 (doi: 10.3189/ 172756501781831800)

Rignot E, Box JE, Burgess E and Hanna E (2008) Mass balance of the Greenland ice sheet from 1958 to 2007. Geophys. Res. Lett., 35(20), L20502 (doi: 10.1029/2008GL035417)

Rignot E, Velicogna I, Van den Broeke MR, Monaghan A and Lenaerts J (2011) Acceleration of the contribution of the Greenland and Antarctic ice sheets to sea level rise. Geophys. Res. Lett., 38(5), L05503 (doi: 10.1029/2011GL046583)

Sabel D, Bartalis Z, Wagner W, Doubkova M and Klein J-P (2012) Development of a Global Backscatter Model in support to the
Sentinel-1 mission design. Remote Sens. Environ., 120, 102-112 (doi: 10.1016/j.rse.2011.09.028)

Schuler TV, Loe E, Taurisano A, Eiken T, Hagen JO and Kohler J (2007) Calibrating a surface mass-balance model for Austfonna ice cap, Svalbard. Ann. Glaciol., 46, 241-248 (doi: 10.3189/ 172756407782871783)

Scott J, Mair D, Nienow P, Parry V and Morris E (2006a) A groundbased radar backscatter investigation in the percolation zone of the Greenland Ice Sheet. Remote Sens. Environ., 104(4), 361-373 (doi: 10.1016/j.rse.2006.05.009)

Scott J, Nienow P, Parry V, Mair D, Morris E and Wingham D (2006b) The importance of seasonal and annual layers in controlling backscattter to radar altimeters across the percolation zone of an ice sheet. Geophys. Res. Lett., 33(24), L24502 (doi: 10.1029/2006GL027974)

Shepherd A and 46 others (2012) A reconciled estimate of ice-sheet mass balance. Science, 338(6111), 1183-1189 (doi: 10.1126/ science.1228102)

Taurisano A and 6 others (2007) The distribution of snow accumulation across Austfonna ice cap Svalbard: direct measurements and modelling. Polar Res., 26(1), 7-13 (doi: 10.1111/ j.1751-8369.2007.00004.x)

Ulander LMH (1996) Radiometric slope correction of syntheticaperture radar images. IEEE Trans. Geosci. Remote Sens., 34(5), 1115-1122 (doi: 10.1109/36.536527)

Wingham DJ and 15 others (2006) CryoSat: a mission to determine the fluctuations in Earth's land and marine ice fields. Adv. Space Res., 37(4), 841-871 (doi: 10.1016/j.asr.2005.07.027)

Zwally HJ and Giovinetto MB (2011) Overview and assessment of Antarctic ice-sheet mass balance estimates: 1992-2009. Surv. Geophys., 32(4-5), 351-376 (doi: 10.1007/s10712-011-9123-5)

MS received 15 March 2013 and accepted in revised form 23 June 2013 